\title{
PENGARUH LITERASI KEUANGAN DAN SIKAP KEUANGAN TERHADAP PERILAKU PENGELOLAAN KEUANGAN MAHASISWA KOTA SAMARINDA
}

\author{
Jeremia Hasiholan Napitupulu ${ }^{1}$, Noor Ellyawati ${ }^{2}$, Ratna Fitri Astuti ${ }^{3}$ \\ ${ }^{1}$ Universitas Mulawarman, jeremiahasiholannapitupulu@gmail.com \\ ${ }^{2}$ Universitas Mulawarman, noorellyawati@gmail.com \\ ${ }^{3}$ Universitas Mulawarman, ratna.fitri@fkip.unmul.ac.id
}

\section{DOI}

https://doi.org/10.26740/jupe.v9n3.p138$\underline{144}$

\author{
Article history \\ Received \\ 8 August 2021 \\ Revised \\ 28 August 2021 \\ Accepted \\ 1 Sept 2021
}

\section{How to cite \\ Napitupulu, J. H., Ellyawati, N., \& Astuti, R. F.. (2021). Pengaruh Literasi Keuangan dan Sikap Keuangan Terhadap Perilaku Pengelolaan Keuangan Mahasiswa Kota Samarinda. Jurnal Pendidikan Ekonomi (JUPE), 9(3), 138- 144. \\ https://doi.org/10.26740/jupe.v9n3.p138- $\underline{144}$}

Kata Kunci: literasi keuangan, sikap keuangan, perilaku pengelolaan keuangan.

Keywords: financial literacy, financial attitude, financial management behavior

\section{Corresponding author}

Jeremia Hasiholan Napitupulu, jeremiahasiholannapitupulu@gmail.com

\begin{abstract}
Abstrak
Peranan literasi keuangan dan sikap keuangan menjadi hal penting dalam menimbulkan berbagai perilaku yang bijak pada pengelolaan keuangan mahasiswa. Penelitian ini bertujuan untuk mengetahui bagaimana pengaruh literasi keuangan dan sikap keuangan terhadap perilaku pengelolaan keuangan mahasiswa. Pengumpulan data dilakukan dengan menyebarkan kuesioner kepada 110 mahasiswa kota Samarinda untuk mengetahui tanggapan mengenai keadaan literasi keuangan, sikap keuangan dan perilaku pengelolaan keuangan mahasiswa. Berdasarkan hasil analisis menunjukkan bahwa secara parsial dan simultan, semakin tinggi literasi keuangan dan sikap keuangan maka semakin tinggi perilaku pengelolaan keuangan mahasiswa. Mahasiswa memiliki perilaku yang tergolong baik menunjukkan bahwa mahasiswa mampu mengaplikasikan pengetahuan dan sikap yang dimiliki pada perilaku pengelolaan keuangannya. Optimalisasi literasi dan sikap keuangan diperlukan, sehingga perilaku mahasiswa dalam mengelola keuangan semakin baik dalam rangka menghadapi permasalahan keuangan yang semakin kompleks dimasa depan.
\end{abstract}

Abstract
The role of financial literacy and financial attitude is important in
producing wise behavior in student financial management. This
research aims to determine how the influence of financial literacy and
financial attitudes on student financial management behavior. Data
collection was carried out by distributing questionnaires to 110
Samarinda's students to find out responses to the condition of financial
literacy, financial attitudes and student financial management behavior.
Based on the analysis results show that partially and simultaneously,
the higher the financial literacy and financial attitude, the higher the
student's financial management behavior. Students who have good
behavior show that students are able to apply their knowledge and
attitudes in their financial management behavior. Optimization of
financial literacy and attitudes is needed, so that student's behavior in
managing finances is getting better in order to face increasingly
complex financial problems in the future.




\section{PENDAHULUAN}

Pemahaman akan pentingnya pengelolaan keuangan sangat diperlukan, karena mengelola keuangan menjadi salah satu kenyataan yang selalu dihadapi oleh setiap manusia dalam kehidupannya. Hal tersebut membuat seseorang harus memiliki perilaku yang bijak dalam mengelola keuangan, sehingga tidak terjebak dalam kesulitan keuangan yang dapat menyebabkan kegagalan dalam mengelola keuangan.

Terdapat banyak faktor yang mendasari timbulnya perilaku pengelolaan keuangan yang diterapkan dalam kehidupan sehari-hari, salah satunya literasi keuangan dan sikap keuangan. Literasi dapat diperoleh melalui berbagai sumber seperti pendidikan, text books, seminar dan sebagainya. Sedangkan sikap biasanya terbentuk karena adanya faktor yang berasal dari keadaan pikiran dan emosi dari dalam diri.

Perilaku pengelolaan keuangan menunjukkan bahwa uang memiliki banyak arti sesuai dengan tingkat pemahaman dan kepribadian, diantaranya uang menjadi bagian penting dalam kehidupan, sumber rasa hormat, kualitas hidup, kebebasan dan bahkan kejahatan. Setiap manusia memiliki pola perilaku yang berbeda dalam mengelola keuangan dan biasanya seseorang yang paham dengan kondisi keuangannya mempunyai perilaku pengelolaan keuangan yang bijak. Salah satu perilaku pengelolaan keuangan mahasiswa Kota Samarinda yang dapat dilihat dari kegiatannya dalam memprioritaskan kebutuhan dan mengendalikan pengeluaran.

Berdasarkan angket yang telah dibagikan kepada 50 mahasiswa kota Samarinda diketahui bahwa sebanyak 98\% atau 49 mahasiswa menyadari manfaat yang diperoleh dengan menyusun skala prioritas kebutuhan, tetapi hanya $10 \%$ atau 5 mahasiswa yang menyusun skala prioritas kebutuhan. Hal ini menunjukkan bahwa masih banyak mahasiswa menyadari akan pentingnya skala prioritas kebutuhan, tetapi belum dapat menerapkannya dalam kehidupan. Kelalaian tersebut dapat menyebabkan kesalahan dalam memprioritaskan kebutuhan, sehingga pengeluaran menjadi tidak terkendali.

Pengeluaran yang tidak terkendali pada mahasiswa terlihat dari besaran pengeluaran yang dilakukan selama sebulan. Pengeluaran tersebut diantaranya kurang dari Rp. 500.000,00 dimiliki $48 \%$ atau 24 mahasiswa, Rp $500.000,00$ s.d Rp. 1.000.000,00 dimiliki $44 \%$ atau 22 mahasiswa, serta lebih dari Rp. 1.000.000,00 dimiliki 8\% atau 4 mahasiswa. Besarnya pengeluaran terdapat $32 \%$ atau 16 mahasiswa yang melakukan pengeluaran terbesar terhadap pemenuhan keinginannya. Pada akhirnya, ketidaktelitian dalam mengelola keuangan dapat menyebabkan kesalahan dalam memprioritaskan dan berdampak pada pengeluaran yang tidak dapat dikendalikan.
Beberapa penelitian yang telah dilakukan untuk mengetahui pengaruh literasi keuangan dan sikap keuangan terhadap perilaku pengelolaan keuangan, diantaranya Humaira dan Sagoro (2018) menyimpulkan bahwa literasi keuangan, sikap keuangan dan kepribadian mempengaruhi perilaku manajemen keuangan pada pelaku UMKM Kabupaten Bantul, Djou (2019) menyimpulkan bahwa literasi keuangan dan sikap keuangan mempengaruhi perilaku pengelolaan keuangan pelaku UMKM Kabupaten Ende, serta Dayanti, Susyanti dan Broto (2020) menyimpulkan bahwa literasi keuangan dan sikap keuangan mempengaruhi perilaku pengelolaan keuangan pelaku UMKM Kabupaten Malang. Perbedaan dari penelitian sebelumya pada penelitian ini, yaitu untuk mengetahui bagaimana pengaruh faktor yang diteliti terhadap perilaku pengelolaan keuangan adalah literasi keuangan dan sikap keuangan, serta dengan mahasiswa Kota Samarinda sebagai subjek penelitian.

\section{Literasi Keuangan $\left(\mathbf{X}_{1}\right)$}

Rapih (2016) menyatakan bahwa literasi keuangan ditunjukkan dalam bentuk kemampuan untuk memilah kebutuhan keuangan, membahas tentang permasalahan keuangan, merencanakan masa depan, dan menanggapi dengan bijak untuk peristiwa kehidupan yang mempengaruhi keputusan keuangan sehari-hari. Keterampilan dalam mengelola keuangan menjadi hal yang perlu dimiliki dalam meminimalisir kesulitan keuangan yang akan dihadapi, seperti kesalahan dalam merencanakan keuangan yang menyebabkan pengeluaran menjadi tak terkendali. Gunawan, Pulungan dan Koto (2019) bahwa pengelolaan keuangan yang didasarkan pada pemahaman mengelola keuangan dapat membantu mengambil keputusan keuangan yang baik dan teratur.

Laily (2016) mengatakan bahwa mahasiswa yang memiliki pengetahuan dan kemampuan dalam mengelola keuangannya dengan baik biasanya menunjukkan perilaku pengambilan keputusan yang bijak tentang keuangan. Ulfatun, Udhma dan Dewi (2016) mengatakan untuk mencapai hal tersebut, terdapat beberapa pengetahuan yang diperlukan antara lain: 1) Pengetahuan Umum Tentang Keuangan, 2) Pengetahuan Simpanan dan Pinjaman, 3) Pengetahuan Asuransi, dan 4) Pengetahuan Investasi.

\section{Sikap Keuangan $\left(\mathbf{X}_{2}\right)$}

Prihartono dan Asandimitra (2018) menyatakan bahwa sikap keuangan merupakan pandangan mengenai uang dilihat dari aspek psikologis yang ditunjukkan dengan kemampuan mengontrol keuangan, pembuatan rencana keuangan, membuat anggaran, serta tindakan dalam pengambilan keputusan keuangan yang tepat. Humaira dan Sagoro (2018) menyatakan dimana keadaan pikiran, pendapat, serta penilaian tentang keuangan pribadi yang diterapkan dapat membentuk sikap keuangan. Sikap keuangan juga dapat diartikan sebagai penerapan prinsip 
keuangan untuk menciptakan dan mempertahankan nilai melalui pengambilan keputusan dan pengelolaan sumber daya keuangan yang tepat.

Rustiaria (2017) menjelaskan bahwa sikap keuangan yang tidak baik dapat memunculkan sifat dan perilaku keserakahan terlebih jika digunakan secara sembarangan. Adiputra, Suprastha dan Tania (2021) menyatakan untuk mencapai sikap keuangan yang baik terdapat beberapa sikap yang harus dimiliki diantaranya: 1) Rencana Penghematan, 2) Manajemen Keuangan Pribadi, dan 3) Kemampuan Keuangan Masa Depan.

\section{Perilaku Pengelolaan Keuangan (Y)}

Amanah, Iridianty dan Rahardian (2016) mengatakan bahwa perilaku pengelolaan keuangan diwujudkan sebagai perilaku dalam mengatur keuangan dari sudut pandang psikologi dan kebiasaan. Kebiasaan perilaku keuangan yang baik timbul dengan adanya keputusan yang rasional dalam mengelola keuangan, sehingga cara yang tepat membuat seseorang tidak terjebak dalam pemenuhan keinginan yang tidak terkendali.

Suwatno, Waspada dan Mulyani (2019) berpendapat bahwa perilaku pengelolaan keuangan yang sehat dapat ditunjukkan melalui adanya aktivitas perencanaan, pengelolaan serta pengendalian keuangan yang baik. Yunita (2020) menyebutkan bahwa terdapat beberapa perilaku yang harus tercermin dalam mengelola keuangan diantaranya, 1) Membelanjakan Uang Sesuai Kebutuhan, 2) Membayar Kewajiban Tepat Waktu, 3) Merencanakan Keuangan Demi Keperluan Dimasa Depan, 4) Menabung, dan 5) menyisihkan uang untuk kebutuhan diri sendiri dan keluarga.

\section{Pengembangan Hipotesis}

Sudarman (2018) menyatakan bahwa hipotesis diartikan sebagai suatu pernyataan berisi prediksi yang berkenaan dengan hasil penelitian. Hipotesis pada penelitian ini, yaitu:

1. Literasi keuangan $\left(\mathrm{X}_{1}\right)$ berpengaruh terhadap perilaku pengelolaan keuangan $(\mathrm{Y})$.

2. Sikap keuangan $\left(\mathrm{X}_{2}\right)$ berpengaruh terhadap perilaku pengelolaan keuangan $(\mathrm{Y})$.

3. Literasi keuangan $\left(X_{1}\right)$ dan sikap keuangan $\left(X_{2}\right)$ berpengaruh terhadap perilaku pengelolaan keuangan (Y).

Dugaan ini mengacu pada beberapa penelitian yang telah dilakukan diantaranya Humaira dan Sagoro (2018) menyimpulkan bahwa literasi keuangan, sikap keuangan dan kepribadian mempengaruhi perilaku manajemen keuangan pada pelaku UMKM Kabupaten Bantul, Djou (2019) menyimpulkan bahwa literasi keuangan dan sikap keuangan mempengaruhi perilaku pengelolaan keuangan pelaku UMKM Kabupaten Ende, serta (Dayanti, Susyanti dan Broto (2020) menyimpulkan bahwa literasi keuangan dan sikap keuangan mempengaruhi perilaku pengelolaan keuangan pelaku UMKM Kabupaten Malang.

Perbedaan dari penelitian sebelumya pada penelitian ini, yaitu untuk mengetahui bagaimana pengaruh faktor yang diteliti terhadap perilaku pengelolaan keuangan adalah literasi keuangan dan sikap keuangan, serta dengan mahasiswa Kota Samarinda sebagai subjek penelitian.

\section{METODE}

Jenis riset yang digunakan pada penelitian ini adalah asosiatif dengan pendekatan kuantitatif, serta melalui teknik analisis regresi linear berganda. Teknik ini berguna untuk melihat ada atau tidaknya pengaruh antara varibel bebas dan terikat yang diteliti. Variabel yang akan diteliti antara lain, literasi keuangan $\left(\mathrm{X}_{1}\right)$, sikap keuangan $\left(\mathrm{X}_{2}\right)$ sebagai variabel independen dan perilaku pengelolaan keuangan (Y) sebagai variabel dependen.

Populasi dalam penelitian ini adalah mahasiswa Pendidikan Ekonomi yang berjumlah 151 mahasiswa. Teknik simple random sampling digunakan untuk mengambil anggota sampel dari populasi secara acak. Jumlah sampel yang diperlukan sebanyak 110 mahasiswa dengan menggunakan rumus slovin sebagai berikut (Sugiyono, 2017).

$\mathrm{n}=\frac{\mathrm{N}}{1+\mathrm{Ne}^{2}}$

$\mathrm{n}=\frac{151}{1+(151)(0,05)^{2}}=109,61$ dibulatkan menjadi 110

Keterangan:

$\mathrm{n}=$ Jumlah sampel

$\mathrm{N}=$ Jumlah populasi

$\mathrm{e}^{2}=$ Taraf nyata atau batas kesalahan

Penghimpunan data dilakukan dengan cara menyebarkan kuesioner dengan skala pengukuran likert. Sudarman (2018) menjelaskan bahwa kuesioner merupakan instrumen yang terdiri dari beberapa pertanyaan atau pernyataan yang disusun berdasarkan indikator suatu variabel penelitian. Sebelum kuesioner disebarkan terdapat beberapa tahapan yang perlu dilakukan, diantaranya uji validitas dan reliabilitas kuesioner. Suatu pernyataan dikatakan valid apabila nilai $\mathrm{r}_{\text {hitung }}>\mathrm{r}_{\text {tabel}}$, sedangkan suatu instrumen dikatakan reliable apabila nilai cronbach alpha $>0,60$.

Data yang diperoleh dianalisis dengan menggunakan analisis sebagai berikut: 1) asumsi klasik yang digunakan untuk melihat persamaan garis regresi yang diperoleh dapat dipergunakan (layak) dan linear, maka uji yang dilakukan diantaranya normalitas, multikolinieritas, heteroskedastisitas dan liniaritas. 2) Analisis regresi linear berganda untuk menganalisis pengaruh variabel independen (X) terhadap variabel dependen (Y). 3) Uji-F yang pada dasarnya untuk melihat pengaruh secara 
simultan variabel independen terhadap variabel dependen. 4) Uji-t digunakan untuk mengetahui signifikansi pengaruh secara parsial variabel independen terhadap variabel dependen. 5) Koefisien determinasi yang pada dasarnya digunakan untuk mengetahui berapa besar pengaruh variabel independen terhadap variabel dependen.

\section{HASIL DAN PEMBAHASAN}

Tabel 1 Reliabilitas Instrumen

\begin{tabular}{lcc}
\hline \multicolumn{1}{c}{ Variabel } & Cronbach's & Keterangan \\
\hline Literasi Keuangan $\left(\mathrm{X}_{1}\right)$ & 0,813 & Reliable \\
Sikap Keuangan $\left(\mathrm{X}_{2}\right)$ & 0,746 & Reliable \\
Perilaku Pengelolaan & 0,867 & Reliable \\
Keuangan $(\mathrm{Y})$ & & \\
\hline
\end{tabular}

Sumber: Data primer diolah (2021)

Tabel 1 menunjukkan bahwa instrumen literasi keuangan $\left(\mathrm{X}_{1}\right)$, sikap keuangan $\left(\mathrm{X}_{2}\right)$ dan perilaku pengelolaan keuangan (Y) diperoleh nilai cronbach's alpha $>0,60$, sehingga kuesioner layak untuk disebarkan.

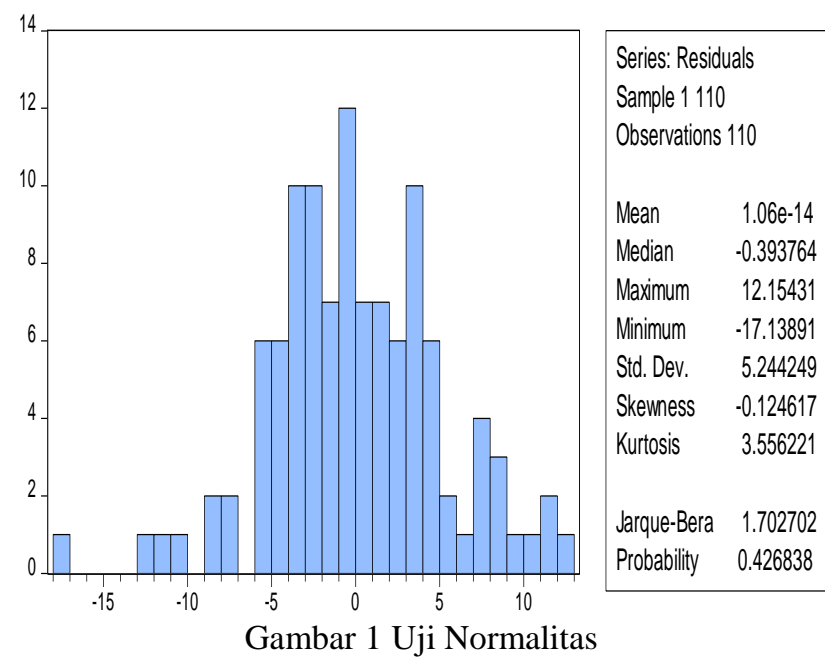

Sumber: Data primer diolah (2021)

Gambar 1 menunjukkan bahwa hasil uji normalitas jarque-bera nilai probability sebesar 0,427>0,05, maka data yang diperoleh terdistribusi dengan normal. Data yang terdistribusi dengan normal dapat dilakukan analisis parametrik seperti uji t, uji f dan sebagainya pada analisis regresi.

Tabel 2 Uji Multikolinieritas

\begin{tabular}{lccc} 
Variabel & $\begin{array}{c}\text { Coefficient } \\
\text { Variance }\end{array}$ & $\begin{array}{c}\text { Uncentered } \\
\text { VIF }\end{array}$ & $\begin{array}{c}\text { Centered } \\
\text { VIF }\end{array}$ \\
\hline \hline C & 23.40945 & 91.91251 & NA \\
Literasi & 0.007731 & 93.02161 & 1.187482 \\
Keuangan & & & \\
Sikap & 0.014365 & 57.32495 & 1.187482 \\
Keuangan & & & \\
\hline
\end{tabular}

Sumber: Data primer diolah (2021)

Tabel 2 menunjukkan bahwa hasil uji multikolinieritas nilai Centered VIF sebesar $1,187<10$, maka tidak terjadi multikolinieritas antara variabel bebas yaitu literasi keuangan $\left(\mathrm{X}_{1}\right)$ dan sikap keuangan $\left(\mathrm{X}_{2}\right)$. Setelah pengujian tingkat korelasi antara variabel bebas memenuhi syarat pada uji multikolinieritas, maka uji heteroskedastisitas dapat dilakukan untuk mengetahui ada atau tidaknya ketidaksamaan varian pada persamaan regresi yang diteliti.

Tabel 3 Uji Heteroskedastisitas

\begin{tabular}{|c|c|c|}
\hline \multicolumn{3}{|c|}{ Heteroskedasticity Test: White } \\
\hline F-statistic & 0.886685 Prob. $F(5,104)$ & 0.4929 \\
\hline Obs*R-squared & 4.497478 Prob. Chi-Square(5) & 0.4802 \\
\hline $\begin{array}{l}\text { Scaled explained } \\
\text { SS }\end{array}$ & 5.439007 Prob. Chi-Square(5) & 0.3647 \\
\hline
\end{tabular}

Tabel 3 menunjukkan bahwa hasil uji heteroskedastisitas dengan metode white test diperoleh nilai probability obs*r-squared pada prob.chi-square (5) sebesar 0,480 >0,05, maka tidak terjadi heteroskedastisitas pada model regresi yang diteliti. Model regresi yang telah memiliki kesamaan varian dapat dilakukan uji linieritas untuk mengetahui ada atau tidaknya hubungan yang linier antara variabel bebas dengan variabel terikat yang diteliti.

Tabel 4 Uji Linieritas

\begin{tabular}{|c|c|c|c|}
\hline \multicolumn{4}{|c|}{ Ramsey RESET Test } \\
\hline & Value & $\mathrm{df}$ & Probability \\
\hline t-statistic & 0.058551 & 106 & 0.9534 \\
\hline F-statistic & 0.003428 & $(1,106)$ & 0.9534 \\
\hline Likelihood ratio & 0.003558 & 1 & 0.9524 \\
\hline
\end{tabular}

Sumber: Data primer diolah (2021)

Tabel 4 menunjukkan bahwa hasil uji linieritas dengan metode ramsey RESET test diperoleh nilai probability $f$ statistic sebesar 0,953>0,05, maka terdapat hubungan linier antara literasi keuangan $\left(\mathrm{X}_{1}\right)$, sikap keuangan $\left(\mathrm{X}_{2}\right)$ dan perilaku pengelolaan keuangan (Y). Setelah keseluruhan asumsi klasik telah terpenuhi, maka data dapat dianalisis dengan regresi linier berganda.

Tabel 5 Uji Regresi Linier Berganda

\begin{tabular}{lcccc}
\hline Variabel & Coefficient & Std. Error & t-Statistic & Prob. \\
\hline \hline C & 5.377939 & 4.838332 & 1.111528 & 0.2688 \\
Literasi & 0.425705 & 0.087927 & 4.841563 & 0.0000 \\
$\begin{array}{l}\text { Keuangan } \\
\text { Sikap }\end{array}$ & 0.736002 & 0.119856 & 6.140733 & 0.0000 \\
Keuangan & & & & \\
\hline \hline
\end{tabular}

Sumber: Data primer diolah (2021)

1. Pada variabel literasi keuangan $\left(X_{1}\right)$ diperoleh nilai $\mathrm{t}_{\text {hitung }}=4,841>\mathrm{t}_{\text {tabel }}=1,982$ dan nilai signifikansi 0,000 $<0,05$, memiliki arti bahwa secara parsial literasi keuangan $\left(\mathrm{X}_{1}\right)$ berpengaruh signifikan terhadap perilaku pengelolaan keuangan $(\mathrm{Y})$.

2. Pada variabel sikap keuangan $\left(\mathrm{X}_{2}\right)$ diperoleh nilai $\mathrm{t}_{\text {hitung }}$ $=6,141>t_{\text {tabel }}=1,982$ dan nilai signifikansi $0,000<$ 
0,05, memiliki arti bahwa secara parsial sikap keuangan $\left(\mathrm{X}_{2}\right)$ berpengaruh signifikan terhadap perilaku pengelolaan keuangan (Y).

\section{Pengaruh Literasi Keuangan Terhadap Perilaku Pengelolaan Keuangan Mahasiswa}

Hasil analisis pada variabel literasi keuangan $\left(\mathrm{X}_{1}\right)$ diperoleh nilai $t_{\text {hitung }}=4,841>\mathrm{t}_{\text {tabel }}=1,982$ dan nilai signifikansi $0,000<0,05$, memiliki arti bahwa secara parsial literasi keuangan $\left(\mathrm{X}_{1}\right)$ berpengaruh signifikan terhadap perilaku pengelolaan keuangan (Y). Hal tersebut menunjukkan bahwa mahasiswa mampu mengimplementasikan berbagai macam pengetahuan keuangan, sehingga dapat menimbulkan perilaku yang baik dalam merencanakan dan mengendalikan keuangannya. Hasil penelitian ini sejalan dengan beberapa penelitian yang dilakukan, diantaranya Busyro (2019) menyimpulkan bahwa mahasiswa memiliki pengetahuan yang baik mengenai keuangan dapat merencanakan dan mengontrol keuangannya dengan baik, Sugiharti dan Maula (2019) menyimpulkan bahwa mahasiswa mampu mengimplementasikan berbagai macam aspek keuangan, sehingga dapat menimbulkan perilaku yang bijak dalam merencanakan dan mengontrol keuangannya. Hasil penelitian ini berbanding terbalik dengan Herdjiono dan Damanik (2016) yang menyimpulkan bahwa literasi keuangan tidak berpengaruh terhadap perilaku pengelolaan keuangan.

Pengetahuan keuangan yang dimiliki mahasiswa berperan dalam menimbulkan perilaku yang baik pada pengelolaan keuangan diantaranya, pengetahuan umum tentang keuangan, pengetahuan simpanan dan pinjaman, pengetahuan asuransi dan pengetahuan investasi. Hal ini menunjukkan bahwa mahasiswa menguasai pengetahuan dan kemampuan yang dibutuhkan, sehingga timbul perilaku yang bijak dalam pengelolaan keuangannya. Sejalan dengan pendapat Laily (2016) bahwa mahasiswa yang memiliki kemampuan dan pengetahuan yang baik dalam mengelola keuangan biasanya menunjukkan perilaku pengambilan keputusan yang bijak tentang keuangan. Mahasiswa perlu membangkitkan literasi keuangan lebih baik lagi dengan cara mengenal lebih dalam mengenai fungsi uang selain sebagai alat tukar, sehingga perilakunya dalam merencanakan keuangan demi keperluan dimasa depan juga meningkat

\section{Pengaruh Sikap Keuangan Terhadap Perilaku Pengelolaan Keuangan Mahasiswa}

Hasil analisis pada variabel sikap keuangan $\left(\mathrm{X}_{2}\right)$ diperoleh nilai $t_{\text {hitung }}=6,141>t_{\text {tabel }}=1,982$ dan nilai signifikansi $0,000<0,05$, memiliki arti bahwa secara parsial sikap keuangan $\left(\mathrm{X}_{2}\right)$ berpengaruh signifikan terhadap perilaku pengelolaan keuangan (Y). Hal tersebut menunjukkan bahwa sikap waspada dan bertanggung jawab mengakibatkan perilaku yang baik dalam mengelola keuangan yang dimiliki. Hasil penelitian ini sejalan dengan beberapa penelitian yang telah dilakukan, diantaranya Qamar, Khemta dan Jamil (2016) menyimpulkan bahwa kewaspadaan mengenai keuangan berdampak pada rutinitas dalam mengelola keuangan, Rustiaria (2017) menyimpulkan bahwa sikap yang bertanggung jawab mengakibatkan perilaku yang waspada dalam mengelola keuangan yang dimiliki. Hasil penelitian ini berbanding terbalik dengan Gahagho, Rotinsulu dan Mandeij (2021) yang menyimpulkan bahwa sikap keuangan tidak berpengaruh terhadap perilaku pengelolaan keuangan.

Sikap keuangan yang dimiliki berperan khusus dalam mengarahkan mahasiswa untuk mempraktikkan perilaku pengelolaan keuangannya. Sikap keuangan yang berperan bagi timbulnya perilaku yang baik dalam mengelola keuangan diantaranya, rencana penghematan, manajemen keuangan pribadi dan kemampuan keuangan dimasa depan. Mahasiswa dengan sikap keuangan yang lebih baik, tentu akan mencerminkan pola perilaku yang jauh lebih baik mengenai keuangannya.

Optimalisasi sikap sangat diperlukan dalam meningkatkan perilaku yang bijak pada pengelolaan keuangan, terutama pada peningkatan kemampuan keuangan masa depan. Mahasiswa juga dapat meningkatkan rutinitasnya untuk melakukan pencatatan atas pengeluaran, sehingga keuangan menjadi lebih terkendali untuk dapat membayar kewajiban dengan tepat waktu. Selain itu, mahasiswa perlu meningkatkan kemampuan keuangan masa depan dengan cara mengkonsultasikan kegiatan keuangannya pada orang tua, agar mahasiswa dapat lebih baik dalam mendayagunakan sumber keuangan untuk memenuhi kebutuhan pribadi

\section{Pengaruh Literasi Keuangan dan Sikap Keuangan} Terhadap Perilaku Pengelolaan Keuangan Mahasiswa

Hasil analisis pada variabel perilaku pengelolaan keuangan $(\mathrm{Y})$ diperoleh nilai $\mathrm{f}_{\text {hitung }}=50,335>\mathrm{f}_{\text {tabel }}=3,08$ dan nilai signifikan $0,000<0,05$, memiliki arti bahwa secara simultan variabel literasi keuangan $\left(\mathrm{X}_{1}\right)$ dan sikap keuangan $\left(\mathrm{X}_{2}\right)$ berpengaruh secara simultan terhadap variabel perilaku pengelolaan keuangan (Y). Hal tersebut menunjukkan bahwa literasi keuangan dan sikap keuangan yang dimiliki mahasiswa berperan penting dalam mengarahkan mahasiswa untuk berperilaku bijak pada pengelolaan keuangannya. Hasil penelitian ini sejalan dengan penelitian yang dilakukan, diantaranya Yap, Komalasari dan Hadiansah (2016) menyimpulkan bahwa literasi keuangan dan sikap keuangan berperan penting pada perilaku seseorang dalam mengelola keuangan.

Perilaku mahasiswa dalam pengelolaan keuangan yang baik ditunjukkan pada aktivitasnya dalam membelanjakan uang sesuai kebutuhan, membayar kewajiban tepat waktu, merencanakan keuangan demi keperluan dimasa depan, 
menabung dan menyisihkan uang untuk kebutuhan pribadi dan keluarga. Sejalan dengan pendapat Suwatno, Waspada dan Mulyani (2019) bahwa perilaku pengelolaan keuangan yang sehat dapat ditunjukkan melalui adanya aktivitas perencanaan dan pengendalian keuangan yang baik.

Sebagai pelaku ekonomi, hal yang tepat dilakukan mahasiswa adalah mengutamakan kebutuhan yang menjadi prioritas bukan pada eksistensi lingkungan sekitar (Kurniawan, 2017). Pentingnya kesadaran akan sumber daya dan keinginan untuk mengatur keuangan yang dimiliki agar dapat digunakan untuk satu bulan, membuat mahasiswa harus membelanjakan uang sesuai dengan kebutuhan. Hal ini membuuat mahasiswa harus memiliki aktivitas perencanaan dan pengendalian keuangan yang baik.

\section{SIMPULAN}

Berdasarkan hasil analisis dan pembahasan yang telah dipaparkan dapat ditarik beberapa kesimpulan, diantaranya: (1) Semakin tinggi literasi keuangan $\left(\mathrm{X}_{1}\right)$ mahasiswa, maka semakin tinggi perilaku pengelolaan keuangan (Y) yang menunjukkan penguasaan atas pengetahuan mengenai keuangan, berperan penting bagi mahasiswa untuk menimbulkan perilaku yang baik dalam mengelola keuangan. Mahasiswa memiliki literasi keuangan yang tergolong baik dan menunjukkan bahwa mahasiswa menguasai pengetahuan yang dibutuhkan dalam mengelola keuangan. (2) Semakin tinggi sikap keuangan $\left(\mathrm{X}_{2}\right)$ mahasiswa, maka semakin tinggi perilaku pengelolaan keuangan (Y) yang menunjukkan kewaspadaan dan tanggung jawab terhadap keuangan yang dimiliki, dapat mengarahkan mahasiswa untuk mempraktikkan perilaku pengelolaan keuangannya. Mahasiswa memiliki sikap keuangan yang tergolong sangat baik dan menunjukkan bahwa mahasiswa memiliki sikap yang berperan khusus dalam mengarahkan untuk berperilaku bijak pada pengelolaan keuangannya. (3) Semakin tinggi literasi keuangan $\left(\mathrm{X}_{1}\right)$ dan sikap keuangan $\left(\mathrm{X}_{2}\right)$, maka semakin tinggi perilaku pengelolaan keuangan (Y) yang menunjukkan peningkatan pengetahuan diikuti dengan cara mahasiswa dalam menyikapi sumber daya yang dimiliki menimbulkan perilaku yang bijak pada pengelolaan keuangan. Mahasiswa memiliki perilaku pengelolaan keuangan yang tergolong baik menunjukkan bahwa mahasiswa mampu mengaplikasikan pengetahuan dan sikap yang dimiliki pada perilaku pengelolaan keuangannya.

\section{DAFTAR PUSTAKA}

Adiputra, I. G., Suprastha, N., dan Tania, L. (2021). The Influence Of Financial Knowledge, Financial Attitude Dan Locus Of Control On Financial
Behavior Of E-Wallet Users In Jakarta. Journal of Contemporary Issues in Business and Government, 27(1), 3318-3332.

Amanah, E., Iradianty, A., dan Rahardian, D. (2016). Pengaruh Financial Knowledge, Financial Attitude Dan External Locus of Control Terhadap Personal Financial Management Behavior Pada Mahasiswa S1 Universitas Telkom the Influence of Financial Knowledge, Financial Attitude and External Locus of Control on. E-Proceeding of Management, 3(2), 1228-1235.

Busyro, W. (2019). Pengaruh Literasi Keuangan Terhadap Perilaku Pengelolaan Keuangan Mahasiswa (Studi Kasus Pada Mahasiswa Fakultas Ekonomi Dan Bisnis Universitas Muhammadiyah Riau). Jurnal ISLAMIKA, 2(1), 34-37.

Dayanti, F. K., Susyanti, J., dan Broto, M. K. A. (2020). Pengaruh Literasi Keuangan, Pengetahuan Keuangan Dan Sikap Keuangan Terhadap Perilaku Manajemen Keuangan Pada Pelaku Usaha UMKM Fashion Di Kabupaten Malang. Jurnal Riset Manajemen Fakultas Ekonomi Unisma, 160-174.

Djou, L. G. (2019). Analisis Pengaruh Literasi Keuangan, Sikap Keuangan dan Kepribadian Terhadap Perilaku Pengelolaan Keuangan Umkm di Kabupaten Ende. Jurnal Magisma, 7(2), 123-134.

Gahagho, Y. D., Rotinsulu, T. O., dan Mandeij, D. (2021). Pengaruh Literasi Keuangan, Sikap Keuangan Dan Sumber Pendapatan Terhadap Perilaku Pengelolaan Keuangan Mahasiswa Fakultas Ekonomi Dan Bisnis Unsrat Dengan Niat Sebagai Variabel Intervening. Jurnal EMBA, 9(1), 543-555.

Gunawan, A., Pulungan, D. R., dan Koto, M. (2019). Seminar Nasional \& Call For Paper Seminar Bisnis Magister Manajemen. Seminar Bisnis Magister Manajemen (SAMBIS-2019).

Herdjiono, I., dan Damanik, L. A. (2016). Pengaruh Financial Attitude, Financial Knowledge, Parental Income Terhadap Financial Management Behavior. Jurnal Manajemen Teori Dan Terapan| Journal of Theory and Applied Management, 9(3), 226-241.

Humaira, I., dan Sagoro, E. M. (2018). Pengaruh Pengetahuan Keuangan, Sikap Keuangan, Dan Kepribadian Terhadap Perilaku Manajemen Keuangan Pada Pelaku Umkm Sentra Kerajinan Batik Kabupaten Bantul. Nominal, 7(1), 96-110.

Kurniawan, C. (2017). Analisis Faktor-Faktor yang Mempengaruhi Perilaku Konsumtif Ekonomi pada Mahasiswa. Jurnal Media Wahana Ekonomika, 13(4), 107-118.

Laily, N. (2016). Pengaruh Literasi Keuangan Terhadap Perilaku Mahasiswa Dalam Mengelola Keuangan. Journal of Accounting and Business Education, 1(4), 1-17.

Prihartono, M. R. D., dan Asandimitra, N. (2018). Analysis Factors Influencing Financial Management Behaviour. International Journal of Academic Research in Business and Social Sciences, 8(8), 308-326.

Qamar, M. A. J., Khemta, M. A. N., dan Jamil, H. (2016). How Knowledge and Financial Self-Efficacy 
Moderate the Relationship between Money Attitudes and Personal Financial Management Behavior. European Online Journal of Natural and Social Sciences, 5(2), 296-308.

Rapih, S. (2016). Pendidikan Literasi Keuangan Pada Anak: Mengapa dan Bagaimana? Scholaria, 6(2), 14-28.

Rustiaria, A. P. (2017). Pengaruh pengetahuan keuangan, sikap keuangan, dan tingkat pendidikan terhadap perilaku pengelolaan keuangan keluarga. Journal of Business and Banking, 12(3), 1-16.

Sudarman. (2018). Metode Penelitian Pendidikan: Buku Ajar Pendukung Model Blended Learning Berbasis Nine Intructional Events. Mulawarman University Press.

Sugiharti, H., dan Maula, K. A. (2019). Pengaruh Literasi Keuangan Terhadap Perilaku Pengelolaan Keuangan Mahasiswa. Journal of Accounting and Finance, 4(2), 804-818.

Sugiyono. (2017). Metode Penelitian Kuantitatif, Kualitatif, dan $R \& D$. ALFABETA.

Suwatno, Waspada, I. P., dan Mulyani, H. (2019). Meningkatkan Perilaku Pengelolaan Keuangan Mahasiswa Melalui Financial Literacy Dan Financial Sel Efficacy. JPAK: Jurnal Pendidikan Akuntansi Dan Keuangan, 8(1), 87-96.

Ulfatun, T., Udhma, U. S., dan Dewi, R. S. (2016). Analisis Tingkat Literasi Keuangan Mahasiswa Fakultas Ekonomi Universitas Negeri Yogyakarta Tahun Angkatan 2012-2014. Pelita, 9(2), 1-13.

Yap, R. J. C., Komalasari, F., dan Hadiansah, I. (2016). The Effect of Financial Literacy and Attitude on Financial Management Behavior and Satisfaction. Journal of Administrative Science and Organization, 23(3), 140-146.

Yunita, N. (2020). Pengaruh Gender Dan Kemampuan Akademis Terhadap Literasi Keuangan dalam Perilaku Pengelolaan Keuangan Pada Mahasiswa Jurusan Akuntansi. Platform Riset Mahasiswa Akuntansi, 01(02), 1-12. 